\title{
Thiothixene Hydrochloride
}

\author{
National Cancer Institute
}

\section{Source}

National Cancer Institute. Thiothixene Hydrochloride. NCI Thesaurus. Code C47753.

The hydrochloride salt form of thiothixene, a thioxanthene derivative and a dopamine antagonist with antipsychotic property. Thiothixene blocks postsynaptic dopamine receptors in the mesolimbic system and medullary chemoreceptor trigger zone, thereby decreasing dopamine activity leading to decreased stimulation of the vomiting center and psychotic effects, such as hallucinations and delusions. In addition, this agent blocks the D2 somatodendritic autoreceptor, thereby increasing dopamine turnover. Thiothixene possesses weak affinity for the histamine $\mathrm{H} 1$ and alpha-adrenergic receptors. 